\title{
FONTAN CONVERSION TO CAVOPULMONARY CONNECTION AND ARRHYTHMIA CIRCUIT CRYOABLATION
}

Constantine Mavroudis, MD

Carl L. Backer, MD

Barbara J. Deal, MD

Christopher L. Johnsrude, MD
Objectives: We review our surgical experience patients with atriopulmonary Fontan operations who had obstructive or arrhythmia indications for conversion to total cavopulmonary artery connections, arrhythmia circuit cryoablation, and placement of atrial antitachycardia pacemaker. Methods: Fourteen patients (mean age $14 \pm 4$ years) had conversion to total cavopulmonary artery connection $8 \pm 3$ years after the original atriopulmonary Fontan operation primarily for atrial arrhythmias in 11, obstructive lesions in 2 , and bradycardia with cyanosis in 1 . Arrhythmia circuit cryoablation was performed on 11 patients and 10 had atrial antitachycardia pacemakers. Preoperative functional New York Heart Association class was IV in 9, III in 4, and II in 1. Results: One patient had brain death (7\%) presumably caused by resternotomy complications despite an excellent hemodynamic result. Another required reoperation for a maldeployed clamshell device after attempted fenestration closure. Average length of stay was $10 \pm 3$ days; chest tubes were removed on day $7 \pm 3$. There were no long-term deaths (mean follow-up 1.7 years, range 5 months to 5 years). Postoperative arrhythmias occurred in five patients, three of whom had successful termination by antitachycardia pacemaker and two who had pharmacologic control of their respective junctional ectopic and slow atrial tachycardia. All patients have improved to New York Heart Association class I or II. Conclusions: Total cavopulmonary artery conversion in association with arrhythmia circuit cryoablation and atrial antitachycardia pacemaker placement can be accomplished with low morbidity and mortality, oftentimes resulting in dramatic increases in functional class and control of life-threatening arrhythmias. (J Thorac Cardiovasc Surg 1998; 115:547-56)
$T^{\mathrm{h}}$ he Fontan operation has undergone a number of major modifications ${ }^{1-5}$ leading to the present-day practice of total cavopulmonary artery connections using lateral tunnel ${ }^{3}$ or extracardiac ${ }^{6}$ techniques. Interatrial fenestration is often, but not always, used

From the Divisions of Cardiovascular-Thoracic Surgery and Cardiology, The Children's Memorial Hospital, and the Departments of Surgery and Pediatrics, Northwestern University Medical School, Chicago, Ill.

Presented at the Second World Congress of Pediatric Cardiology and Cardiac Surgery, Honolulu, Hawaii, May 11-15, 1997.

Received for publication June 13, 1997; revisions requested July 30, 1997; revisions received Sept. 8, 1997; accepted for publication Sept. 8, 1997.

Address for reprints: Constantine Mavroudis, MD, Division of Cardiovascular-Thoracic Surgery, Mail Code 22, Children's Memorial Hospital, 2300 Children's Plaza, Chicago, IL 60614.

Copyright (c) 1998 by Mosby, Inc.

$0022-5223 / 98 \$ 5.00+0 \quad \mathbf{1 2 / 1 / 8 5 9 9 9}$ depending on the number of patient risk factors ${ }^{7,8}$ and institutional experience. ${ }^{9}$

However, a large number of Fontan patients had variations of atriopulmonary artery connections before the present era. These, mostly older patients, are at risk for anatomic obstructions and atrial arrhythmias that usually lead to unfavorable hemodynamics and systemic complications. ${ }^{10,11}$ Recent reports have shown improved functional class in some patients after atriopulmonary artery Fontan conversion to total cavopulmonary artery connection. ${ }^{12-15}$ Concomitant antiarrhythmia therapy consisting of arrhythmia circuit cryoablation in these patients has not been previously reported.

The purpose of this article is to review our surgical experience with patients with atriopulmonary artery Fontan operations who had obstructive anatomic or arrhythmia indications for conversion to total cavopulmonary artery connection, arrhyth- 
mia circuit cryoablation, and placement of atrial antitachycardia pacemaker. Not included in this review are the detailed perioperative electrophysiologic (EP) analyses and relevant discussion that are reported separately. ${ }^{16,17}$

\section{Materials and methods}

Patient population. Between April 1992 and April 1997, 14 patients had conversion from atriopulmonary artery to total cavopulmonary artery Fontan procedures (lateral tunnel in eight, extracardiac in six). There were seven male and seven female patients. The average age at reoperation was $14 \pm 4$ years, and the average time interval between the last Fontan operation and the eventual conversion was $8 \pm 3$ years. Two of these patients had second-time conversions; one had two previously failed atriopulmonary artery connections, and the other had an initial atriopulmonary Fontan operation with acute failure and takedown with a subsequent successful total cavopulmonary artery fenestrated Fontan operation before our current antiarrhythmia protocol was established.

Table I reviews clinical characteristics of our 14 patients, including primary diagnoses, previous Fontan connections, indications for reoperation, components of the Fontan conversion, and outcome. Indications for reoperation were multiple and included New York Heart Association (NYHA) functional class, debilitating atrial arrhythmias, anatomic obstructions, interatrial shunts, and valvular dysfunction. Nine patients were in NYHA class IV, and three of these were considered for heart transplantation because of severe functional limitation. Four were in NYHA class III and the remaining patient was in NYHA class II, but had life-threatening atrial tachycardia, resulting in multiple syncopal episodes. Apart from functional class, the primary indications for surgery were debilitating atrial arrhythmias in 11, severe obstructive lesions in 2, and bradycardia with cyanosis caused by a right-to-left shunt in 1 .

Operative procedure. The precise operative conversion from atriopulmonary artery to cavopulmonary artery Fontan largely depended on the preexisting venopulmonary artery connections and the extent to which further pulmonary artery reconstruction was necessary. Basically, three types of anatomic connections were present: (1) seven patients had atrial compartmentalization with right atrialpulmonary artery anastomosis (five anteroaortic and two retroaortic connections), (2) six patients had a classic right Glenn operation and an atrial-left pulmonary artery anastomosis, and (3) one patient had an excellent anatomic and hemodynamic result from a total cavopulmonary artery, lateral tunnel, Fontan operation that was performed after a remote unsuccessful atriopulmonary connection. The indication for reoperation, reconversion, and cryoablation in the last patient was recurrent, refractory atrial tachycardia with syncope originating in the "left" atrial compartment.

The conduct of the operation was essentially the same for all patients except for patients 1,2, and 11, who did not have concomitant arrhythmia circuit cryoablation.
Careful median sternotomy and relevant dissection were followed by normothermic aortobicaval cardiopulmonary bypass, allowing the heart to beat. In those patients without a right-to-left residual shunt, a right atriotomy was performed for intracardiac EP mapping and cryoablation. A right atrial bipolar wire served as the reference electrode and electrical pathway for arrhythmia stimulation. EP mapping was accomplished by activation sequence mapping during atrial reentry tachycardia (Fig. 1). An endocardial grid was used to sequentially map at least four corridors of atrial tissue, moving superiorly to inferiorly, at four to five sites for each corridor. These results were compared with the preoperative mapping findings. In some cases the areas of interest (e.g., the coronary sinus and tricuspid valve) were in the pulmonary atrium and could not be safely mapped without the risk of air embolism. On the basis of EP arrhythmia circuit identification, multiple cryoablation lesions were placed $\left(-60^{\circ} \mathrm{C}\right.$ for 90 seconds each [Frigitronics, Shelton, Conn.]) in a linear fashion between the coronary sinus os and the inferior vena cava, between the tricuspid or relevant atrioventricular valve anulus and the inferior vena cava (Fig. 2, Area 1), along the full length of the crista terminalis (Fig. 2, Area 2), along the length of the superior septal limbus, and the os of the atrial appendage (Fig. 2, Area 3). In general, Area 1 required 8 to 10 cryoablation lesions, Area 2 required 4 to 6 lesions, and Area 3 required 3 to 5 lesions. Most of the cryoablation lesions were placed during warm cardiopulmonary bypass in a beating heart. When access to the compartmentalized pulmonary atrium was required, further cryoablation was delayed until systemic cooling and cardioplegic arrest were established to avoid air embolism.

For the next phase of the operation (cavopulmonary artery reconstruction), the patient is cooled to $32^{\circ} \mathrm{C}$ with the heart allowed to beat. For those patients with atriopulmonary anastomosis, a standard total cavopulmonary artery reconstruction was accomplished with takedown of the atriopulmonary artery connection. Extensive pulmonary artery reconstruction, when necessary, was performed at this time with polytetrafluoroethylene (PTFE)* or homograft tissue. In those patients with a right Glenn procedure and a right atrial-left pulmonary artery anastomosis, more creative pulmonary artery reconstructions were required (Figs. 3 and 4) with homografts and PTFE tube grafts. At this point, the decision whether to use the intraatrial lateral tunnel technique or the extracardiac connection is made.

The third part of the operation was performed during moderate systemic hypothermia $\left(28^{\circ} \mathrm{C}\right)$ and cold blood cardioplegic arrest. The previously constructed prosthetic atrial septum was resected. During this time, left-sided procedures are performed, including valvular reconstructions, completion of cryoablative lesions, the lateral tunnel reconstruction (when elected), transmural atrial wire placement (Fig. 4) for the antitachycardia pacemaker (Intertach II, Intermedics, Inc., Angleton, Tex.) ${ }^{17}$ ventricular vent placement, atrial wall reduction (performed in

*Gore-Tex graft, registered trademark of W. L. Gore \& Associates, Inc., Elkton, Md. 
Table I. Conversion to cavopulmonary Fontan procedure patients

\begin{tabular}{|c|c|c|c|c|c|c|c|}
\hline $\begin{array}{l}P t . \\
\text { No. }\end{array}$ & $\begin{array}{c}\text { Diagnosis/type of } \\
\text { initial Fontan }\end{array}$ & $\begin{array}{c}\text { Age at } \\
\text { initial } \\
\text { Fontan }\end{array}$ & $\begin{array}{l}\text { Interval } \\
\text { to redo }\end{array}$ & $\begin{array}{l}\text { Age } \\
\text { at } \\
\text { redo }\end{array}$ & Indications* & $\begin{array}{l}\text { Concomitant } \\
\text { procedure }\end{array}$ & Outcome \\
\hline 1 & $\begin{array}{l}\text { L-TGA, VSD, TS, AI; s/p } \\
\text { atriopulmonary an- } \\
\text { teroaortic Fontan }\end{array}$ & 2 & 4 & 6 & $\begin{array}{l}\text { Moderate AP obstruc- } \\
\text { tion with ascites } \\
\text { - Moderate aortic insuffi- } \\
\text { ciency } \\
\text { - Obstruction of right } \\
\text { pulmonary veins } \\
\text { - NYHA class III }\end{array}$ & $\begin{array}{l}\text { Conversion to TCPC } \\
\text { lateral tunnel fenes- } \\
\text { trated }(3.5 \mathrm{~mm}) \text { Fon- } \\
\text { tan } \\
\text { - Aortic valvuloplasty } \\
\text { Reoperation for clam- } \\
\text { shell device deploy- } \\
\text { ment failure }\end{array}$ & $\begin{array}{l}\text { NYHA class II; persis- } \\
\text { tent aortic insuffi- } \\
\text { ciency }\end{array}$ \\
\hline 2 & $\begin{array}{l}\text { Tricuspid atresia, bilateral } \\
\text { SVC; s/p atriopulmo- } \\
\text { nary anteroaortic Fon- }\end{array}$ & $\begin{array}{l}4 \\
14\end{array}$ & $\begin{array}{r}10 \\
1\end{array}$ & 15 & $\begin{array}{l}\text { Severe AP obstruction } \\
\text { with ascites } \\
\text { - NYHA class IV }\end{array}$ & $\begin{array}{l}\text { Conversion to TCPC } \\
\text { lateral tunnel fenes- } \\
\text { trated ( } 6 \mathrm{~mm}) \text { Fontan }\end{array}$ & $\begin{array}{l}\text { Died of presumed } \\
\text { cerebral air embo- } \\
\text { lism }\end{array}$ \\
\hline
\end{tabular}

$\tan$ (valved conduit);

$\mathrm{s} / \mathrm{p}$ conversion to atriopulmonary retroaortic

\section{Fontan}

3 Tricuspid atresia; s/p atriopulmonary anteroaortic Fontan
- Severe SVT

AP obstruction

- NYHA class III
4 Double-inlet left ventricle, subaortic stenosis, right AV valve insufficiency; $\mathrm{s} / \mathrm{p}$ atriopulmonary retroaortic Fontan and subaortic resection

5 Tricuspid atresia; s/p atriopulmonary anteroaortic Fontan

6 Tricuspid atresia; s/p atriopulmonary anteroaortic Fontan

7 L-transposition with single ventricle, mitral stenosis, restricted bulboventricular foramen; s/p Damus-Stansel-Kaye; $\mathrm{s} / \mathrm{p}$ right Glenn and left atriopulmonary retroaortic Fontan
- Conversion to TCPC lateral tunnel fenestrated (5 mm) Fon$\tan$

- Bilateral PA arterioplasty

- Cryoablation of arrhythmia circuit

- Antitachycardia atrial pacemaker

- Conversion to TCPC lateral tunnel Fontan

- Reduction right atrioplasty

- Cryoablation of arrhythmia circuit

- Antitachycardia atrial pacemaker

- Conversion to TCPC lateral tunnel Fontan

- Cryoablation of arrhythmia circuit

- Antitachycardia atrial pacemaker

- Conversion to TCPC lateral tunnel Fontan

- Cryoablation of arrhythmia circuit

- Antitachycardia atrial pacemaker

- Conversion to TCPC extracardiac (20 mm PTFE graft) Fontan

- Ligation hepato-LA communicating vein

- Cryoablation of arrhythmia circuit

- Antitachycardia atrial pacemaker
NYHA class I; digoxin; 6 Episodes of SVT terminated by PM within first 3 mos only, none thereafter

NYHA class I; atenolol; 2 Episodes of SVT terminated by PM within first 3 mos only; slow atrial tachycardia 21 mos postop controlled by atenolol

NYHA class I; no medications; no SVT

NYHA class II; no medications; no SVT 
Table I. Cont'd

\begin{tabular}{|c|c|c|c|c|c|c|c|}
\hline $\begin{array}{l}P t . \\
\text { No. }\end{array}$ & $\begin{array}{l}\text { Diagnosis/type of } \\
\text { initial Fontan }\end{array}$ & $\begin{array}{l}\text { Age at } \\
\text { initial } \\
\text { Fontan }\end{array}$ & $\begin{array}{l}\text { Interval } \\
\text { to redo }\end{array}$ & $\begin{array}{l}\text { Age } \\
\text { at } \\
\text { redo }\end{array}$ & Indications* & $\begin{array}{l}\text { Concomitant } \\
\text { procedure }\end{array}$ & Outcome \\
\hline 8 & $\begin{array}{l}\text { Tricuspid atresia; s/p atrio- } \\
\text { pulmonary retroaortic } \\
\text { Fontan }\end{array}$ & 5.5 & 9.5 & 15 & $\begin{array}{l}\text { - Severe SVT } \\
\text { - Moderate AP obstruction } \\
\text { - NYHA class IV }\end{array}$ & $\begin{array}{l}\text { - Conversion to TCPC extra- } \\
\text { cardiac ( } 24 \text { mm PTFE } \\
\text { graft) Fontan } \\
\text { - PA arterioplasty } \\
\text { - Cryoablation of arrhythmia } \\
\text { circuit } \\
\text { - Antitachycardia atrial pace- } \\
\text { maker }\end{array}$ & $\begin{array}{l}\text { NYHA class I; digoxin; } \\
\text { no SVT }\end{array}$ \\
\hline 9 & $\begin{array}{l}\text { L-TGA, double-inlet left } \\
\text { ventricle, pulmonary } \\
\text { atresia; s/p right Glenn } \\
\text { and left atriopulmonary } \\
\text { retroaortic Fontan }\end{array}$ & 9 & 10 & 19 & $\begin{array}{l}\text { - Severe SVT } \\
\text { - Severe RPA stenosis } \\
\text { - Mild LPA stenosis } \\
\text { - NYHA class IV }\end{array}$ & $\begin{array}{l}\text { - Conversion to TCPC lat- } \\
\text { eral tunnel Fontan } \\
\text { - LPA Palmaz stent } \\
\text { - Cryoablation of arrhythmia } \\
\text { circuit } \\
\text { - Antitachycardia atrial pace- } \\
\text { maker }\end{array}$ & $\begin{array}{l}\text { NYHA class II; digoxin } \\
\text { + procainamide; } \\
\text { adenosine-sensitive } \\
\text { SVT not terminated } \\
\text { by PM } 1 \text { mo postop } \\
\text { controlled by pro- } \\
\text { cainamide }\end{array}$ \\
\hline 10 & $\begin{array}{l}\text { L-TGA, single ventricle } \\
\text { with bulboventricular } \\
\text { foramen, mitral atresia; } \\
\text { s/p right Glenn and left } \\
\text { atriopulmonary retroaor- } \\
\text { tic Fontan }\end{array}$ & 11 & 10 & 21 & $\begin{array}{l}\text { - } \text { Severe SVT } \\
\text { - Pulmonary venous ob- } \\
\text { struction } \\
\text { - NYHA class III }\end{array}$ & $\begin{array}{l}\text { - Conversion to TCPC lat- } \\
\text { eral tunnel Fontan } \\
\text { - Cryoablation of arrhythmia } \\
\text { circuit } \\
\text { - Antitachycardia atrial pace- } \\
\text { maker }\end{array}$ & $\begin{array}{l}\text { NYHA class I; digoxin; } \\
\text { slow atrial tachycar- } \\
\text { dia; SVT terminated } \\
\text { by PM within first } 3 \\
\text { mos, none thereafter }\end{array}$ \\
\hline 11 & $\begin{array}{l}\text { TGA with single RV and } \\
\text { PS; s/p right Glenn and } \\
\text { left atriopulmonary ret- } \\
\text { roaortic Fontan }\end{array}$ & 8 & 8 & 16 & $\begin{array}{l}\text { - Bradycardia } \\
\text { - Mild RPA-venous fistula } \\
\text { with } R \rightarrow L \text { shunt } \\
\text { - NYHA class IV }\end{array}$ & $\begin{array}{l}\text { - Conversion to TCPC extra- } \\
\text { cardiac ( } 22 \mathrm{~mm} \text { aortic ho- } \\
\text { mograft) Fontan } \\
\text { - AAI pacemaker }\end{array}$ & NYHA class I; no SVT \\
\hline 12 & $\begin{array}{l}\text { DORV with mitral atresia; } \\
\text { s/p right Glenn and left } \\
\text { atriopulmonary retroaor- } \\
\text { tic Fontan w/tricuspid } \\
\text { valvuloplasty }\end{array}$ & 5 & 8 & 13 & $\begin{array}{l}\text { - Bradycardia, SVT } \\
\text { - RV dysfunction } \\
\text { - NYHA class IV }\end{array}$ & $\begin{array}{l}\text { Conversion to TCPC extra- } \\
\text { cardiac ( } 24 \text { mm aortic ho- } \\
\text { mograft) Fontan } \\
\text { - Cryoablation of arrhythmia } \\
\text { circuit } \\
\text { - Antitachycardia atrial pace- } \\
\text { maker }\end{array}$ & $\begin{array}{l}\text { NYHA class I; digoxin; } \\
\text { no SVT }\end{array}$ \\
\hline 13 & $\begin{array}{l}\text { L-TGA, single ventricle, } \\
\text { mitral atresia, severe PS; } \\
\text { s/p right Glenn and left } \\
\text { atriopulmonary retroaor- } \\
\text { tic Fontan }\end{array}$ & 4.5 & 7.5 & 12 & $\begin{array}{l}\text { - } \text { Severe SVT } \\
\text { - Persistent LSVC to the } \\
\text { LA with R } \rightarrow \text { L shunt } \\
\text { - Mild LPA stenosis } \\
\text { - NYHA class IV }\end{array}$ & $\begin{array}{l}\text { - Conversion to TCPC extra- } \\
\text { cardiac (composite } 20 \mathrm{~mm} \\
\text { aortic homograft and } 20 \\
\text { mm PTFE graft) Fontan } \\
\text { - Ligation LSVC } \\
\text { - Left PA arterioplasty } \\
\text { - Cryoablation of arrhythmia } \\
\text { circuit } \\
\text { - Antitachycardia atrial pace- } \\
\text { maker }\end{array}$ & $\begin{array}{l}\text { NYHA class I; digoxin; } \\
\text { no SVT }\end{array}$ \\
\hline 14 & $\begin{array}{l}\text { L-TGA, single ventricle } \\
\text { with restrictive bulbo- } \\
\text { ventricular foramen; s/p } \\
\text { AP window and atrio- } \\
\text { pulmonary retroaortic } \\
\text { Fontan with emergency } \\
\text { takedown to S-P shunt; } \\
\text { s/p TCPC lateral tunnel } \\
\text { fenestrated }(5 \mathrm{~mm}) \\
\text { Fontan }\end{array}$ & $\begin{array}{c}7.5 \\
8\end{array}$ & $\begin{array}{c}0.5 \\
7\end{array}$ & 15 & $\begin{array}{l}\text { - Severe SVT } \\
\text { - NYHA class II }\end{array}$ & $\begin{array}{l}\text { - Conversion to TCPC extra- } \\
\text { cardiac ( } 22 \mathrm{~mm} \text { TPFE } \\
\text { graft) Fontan } \\
\text { - Cryoablation of arrhythmia } \\
\text { circuit } \\
\text { - DDD pacemaker }\end{array}$ & $\begin{array}{l}\text { NYHA class I; digoxin; } \\
\text { early heart block; } \\
\text { JET, resolved; no } \\
\text { SVT }\end{array}$ \\
\hline
\end{tabular}

$A I$, Aortic insufficiency; $A P$, atriopulmonary; $A P$ window, aortopulmonary window; $A V$, atrioventricular; $D O R V$, double-outlet right ventricle; $L A$, left atrium; $L P A$, left pulmonary artery; $L S V C$, left superior vena cava; $L-T G A$, L-transposition of the great arteries; $N Y H A$, New York Heart Association; $P A$, pulmonary artery; $P M$, pacemaker; $P S$, pulmonary stenosis; $R A$, right atrium; $R P A$, right pulmonary artery; $R V$, right ventricle; $R \rightarrow L$, right-to-left; $s / p$, status post; $S$ - $P$, systemic-to-pulmonary artery; $S V C$, superior vena cava; $S V T$, supraventricular tachycardia; $T C P C$, total cavopulmonary artery connection; $T S$, tricuspid stenosis; $V S D$, ventricular septal defect.

*AP obstruction was rated by atriopulmonary artery pressure gradient $(\mathrm{mm} \mathrm{Hg}$ ): mild $>1$ to $2 \mathrm{~mm} \mathrm{Hg}$; moderate 2 to $3 \mathrm{~mm} \mathrm{Hg}$; severe $>3 \mathrm{~mm} \mathrm{Hg}$. Severe SVT was defined as SVT causing hemodynamic compromise or syncopal episodes, repeated hospitalizations, and requiring multiple antiarrhythmic medications. 


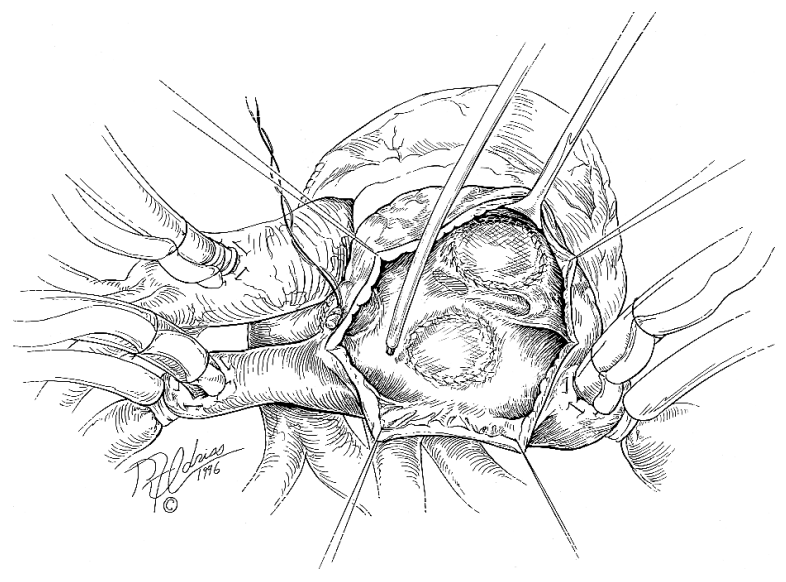

Fig. 1. Diagrammatic representation of an open right atrial view in an atriopulmonary Fontan patient, without residual atrial shunts, who has been placed on normothermic aortobicaval cardiopulmonary bypass en route to EP mapping and arrhythmia circuit cryoablation, cavopulmonary artery conversion, and atrial antitachycardia pacemaker placement. A right atrial bipolar wire served as the reference electrode and electrical pathway for arrhythmia stimulation. A hand-held electrode is used to perform the EP mapping. ${ }^{16}$

most patients), and atriorrhaphy. The atrial pacemaker lead is placed in the "red" atrium by means of the transmural technique reported by Hoyer and associates. ${ }^{18}$ This is followed by de-airing, aortic crossclamp removal, rewarming, vent removal, and extracardiac inferior vena cava connection when elected (Figs. 3, 4). Separation from cardiopulmonary bypass is followed by transesophageal echocardiographic assessment. Patients were usually extubated the following day and underwent EP study and attempted arrhythmia induction before hospital discharge.

Follow-up. Clinical status was assessed on the basis of the functional classification of the NYHA. Arrhythmia assessment included review of clinical history, electrocardiograms, 24-hour continuous Holter monitoring, and pacemaker interrogation at regular 3-month intervals. All patients were placed on lifelong warfarin sodium (Coumadin) therapy (international normalized ratio maintained in the 1.5 to 2.0 range). Specific antiplatelet therapy was not used.

\section{Results}

One perioperative death occurred (7\%) in a patient undergoing second-time Fontan revision. Conversion to total cavopulmonary artery, lateral tunnel, fenestrated Fontan resulted in a favorable hemodynamic result. However, the patient died 4 days later of presumed cerebral air embolism and the low-flow state that accompanied unwanted cavitary entry during the resternotomy.

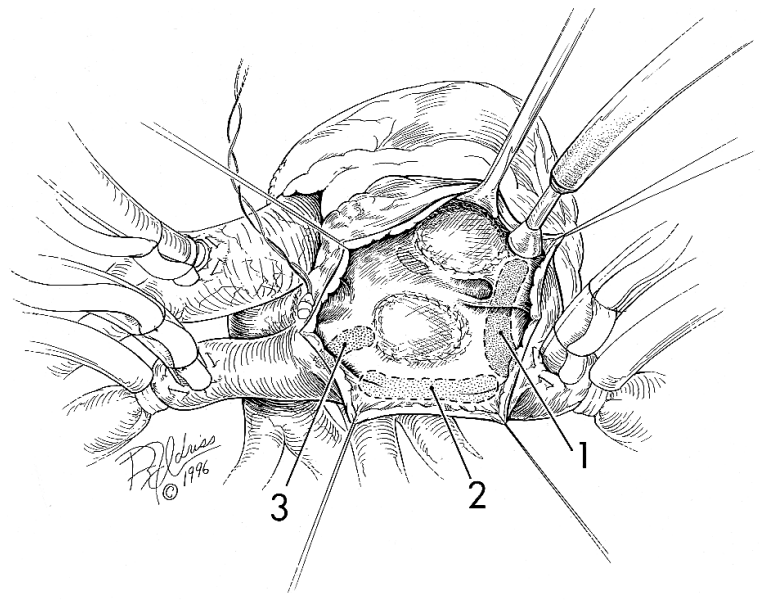

Fig. 2. Diagrammatic representation of an open right atrial view (see Fig. 1). Tachycardia was localized in three major areas: Area 1, the area between the coronary sinus os and the inferior vena cava os, as well as the area between the atrioventricular valve anulus and the inferior vena cava os; Area 2, the lateral atriotomy, which corresponded to the length of the crista terminalis; and Area 3, the region at the superior limbus corresponding to the prior atrial septal defect patch.

Resternotomy was accomplished safely and without significant cavitary entry in 12 of 14 patients. Two patients had unwanted cavitary entry during the resternotomy. One of these (second-time redo Fontan, discussed above) was managed by expeditious femoral-femoral partial cardiopulmonary bypass with intracavitary cardiotomy sucker assistance until completion sternotomy and aortobicaval cardiopulmonary bypass could be established. Another patient was quickly managed with femoral-femoral partial cardiopulmonary bypass but without intracavitary cardiotomy sucker assistance. This prevented air from entering the right atrium and allowed completion sternotomy with aortobicaval conversion without a period of instability. The patient had no complications after a successful Fontan conversion and arrhythmia circuit cryoablation. Subsequently, one patient with a gigantic right anterior atrium was placed on femoro-femoral bypass for atrial decompression before sternotomy. This was then converted to aortobicaval cannulation for the conduct of the operation.

One patient required reoperation (during the same admission) for retrieval of a Lock clamshell device (USCI/C.R. Bard, Inc., Bellerica, Mass.) after a failed attempt at postoperative atrial fenestration closure. We have since abandoned atrial fenes- 


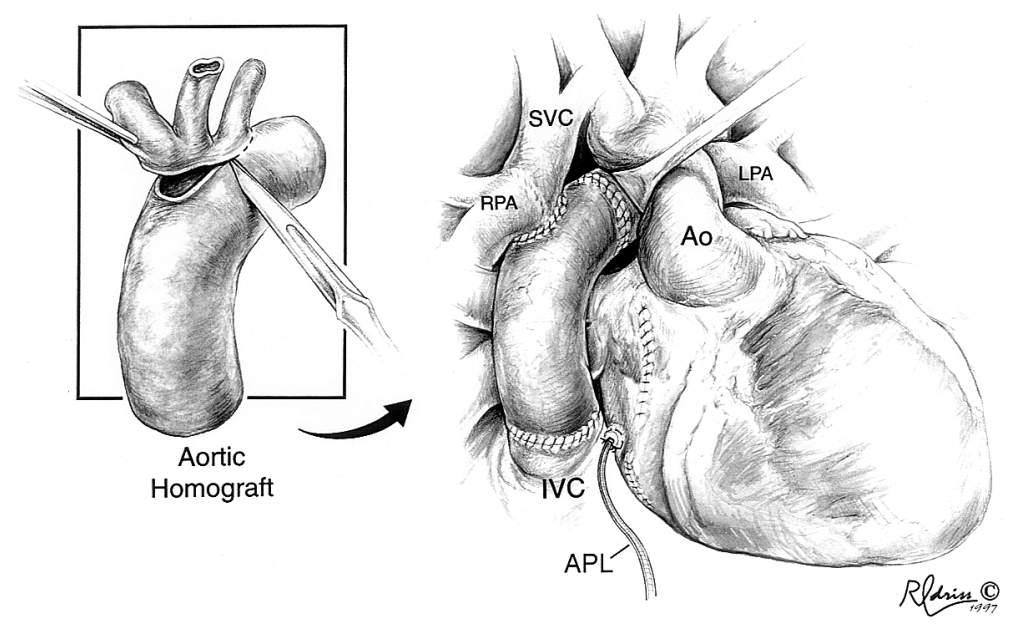

Fig. 3. Diagrammatic representation of a total cavopulmonary artery extracardiac conversion in a patient with an established classic right Glenn/right atrium-to-left pulmonary artery Fontan connection. An aortic homograft was used to connect the left pulmonary artery with the inferior vena cava using the favorable curve of the ascending and transverse arch of the homograft. The Glenn anastomosis was connected side-to-side to the homograft to complete the reconstruction. A transmural bipolar steroid-eluting atrial lead (Medtronic, Inc., Minneapolis, Minn.) is placed in the left atrial appendage for antitachycardia pacemaker placement. $A o$, Aorta; $A P L$, antitachycardia pacemaker lead; $I V C$, inferior vena cava; $S V C$, superior vena cava; $L P A$, left pulmonary artery; $R P A$, right pulmonary artery.

tration for these patients, speculating that postoperative improved hemodynamics and maintenance of systemic oxygen saturation will benefit the patient more than the enhanced cardiac output and obligatory systemic desaturation that accompanies a fenestration. ${ }^{19}$

Transmural steroid-eluting atrial leads and atrial antitachycardia pacemakers were placed in 10 patients who had arrhythmia circuit cryoablation. The rationale for this therapy is that the atrial wire is more easily placed at the revision operation than at a future time of need when obligatory thoracotomy would be necessary, and that the atrial antitachycardia pacemaker may be needed in the event of recurrent atrial tachycardia or the development of a new atrial arrhythmia that might arise from existing atrial suture lines. One patient with sinus bradycardia had an atrial rate-responsive (AAIR) pacemaker and another patient with single ventricle and Ltransposition had a dual-chamber (DDD) pacemaker placed because of atrioventricular dissociation after arrhythmia circuit cryoablation. Postoperatively, the patient regained normal atrioventricular node function without inducible atrial tachycardia, which allowed pacemaker conversion to an AAI mode. Should atrial tachycardia recur, this pacemaker may be manually programmed for ar- rhythmia conversion. The remaining two patients had total cavopulmonary artery conversion before our arrhythmia protocol was initiated.

The average postoperative length of stay in the remaining 13 survivors was $10 \pm 3$ days. Chest tube output was minimal (removal of last chest tube, postoperative day $7 \pm 3$ ). Postoperative atrial tachycardia developed in one patient (No. 9) while receiving inotropic support, requiring procainamide infusion. Another patient (No. 14) had transient junctional ectopic tachycardia develop responding to intravenous amiodarone, which was subsequently withdrawn with no evidence of inducible supraventricular tachycardia before discharge.

No long-term deaths occurred. The mean duration of follow-up in the 13 survivors is 1.7 years (standard deviation 1.6 years, range 5 months to 5 years). All patients are currently considered to be in NYHA class I or II, with resumption of normal activities. Among the 11 patients whose primary indication for reoperation was medically refractory atrial tachycardia, only 2 patients are receiving antiarrhythmic medications other than digoxin. One patient (No. 9, see above) had a single clinical recurrence of adenosine-sensitive atrial tachycardia 4 weeks postoperatively, and no recurrences in the subsequent 14 months while taking procainamide; 


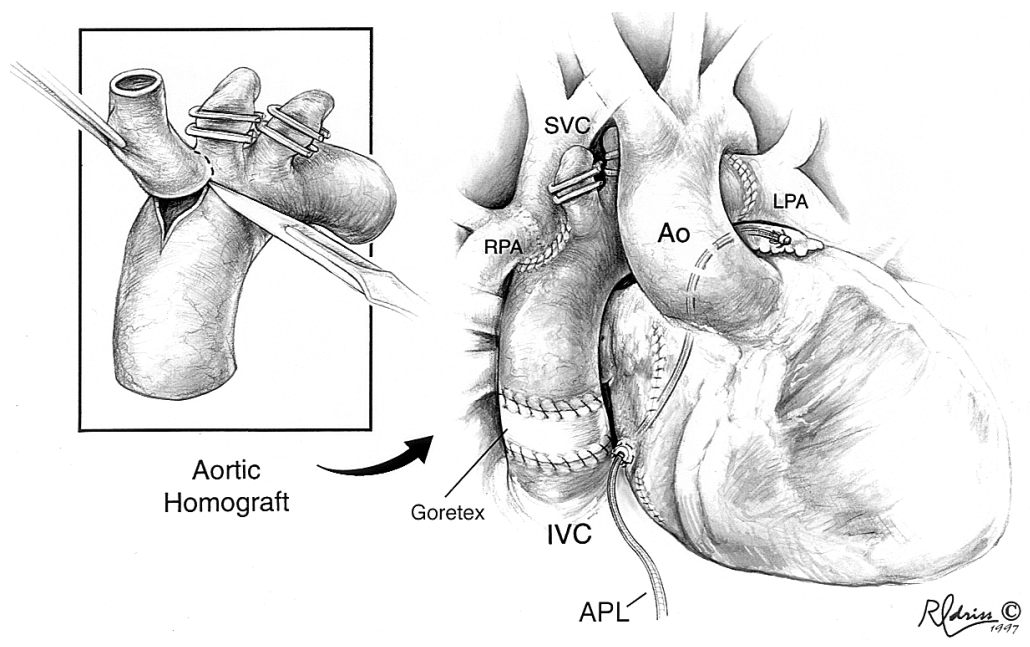

Fig. 4. Total cavopulmonary artery extracardiac Fontan conversion (see Fig. 3). Occasionally, the aortic homograft may require a PTFE graft extension (composite graft) to connect the left pulmonary artery with the inferior vena cava. The Glenn anastomosis can be connected to the homograft as appropriate. Abbreviations as in Fig. 3.

her preoperative arrhythmia was not adenosinesensitive. Another patient (No. 4) with incessant, hemodynamically unstable rapid atrial tachycardia preoperatively, had a slow, asymptomatic atrial tachycardia develop 21 months postoperatively, responding to $\beta$-blocker therapy. In the 10 patients with atrial antitachycardia pacemakers, tachycardia has been successfully detected and terminated by the pacemaker in three of 10 patients (Table I), all occurring in the first 3 months postoperatively, with no subsequent recurrences. None of these patients have been aware of clinical episodes of tachycardia.

\section{Discussion}

Improved modifications of the Fontan operation have resulted in today's accepted practice of total cavopulmonary artery (lateral tunnel or extracardiac) connections. ${ }^{3-11,19}$ Long-term follow-up will determine the efficacy of these techniques with regard to improved hemodynamics and arrhythmia control. 3, 4, 6, 8, 19-23 However, increasing concern exists that atriopulmonary Fontan patients, who underwent repair before the present era, are at risk for anastomotic obstructions and atrial arrhythmias. ${ }^{12-}$ 15, 24-29 In addition, pulmonary arteriovenous fistulas are frequently present in those patients with discontinuous pulmonary arteries caused by an established right Glenn procedure and atrial-left pulmonary artery connections. ${ }^{30}$ Other patients will have leftsided valvular or obstructive lesions, acquired right- to-left shunts, and protein-losing enteropathy develop. ${ }^{10,11,31}$

Reoperation in patients with atriopulmonary Fontan procedures to correct obstructive lesions and convert them to total cavopulmonary artery connections has been successfully performed by several groups. ${ }^{12-15}$ Hemodynamic improvement and increase in functional class were achieved in most patients with acceptable mortality and morbidity. Our experience compares favorably with these reports, demonstrating a low mortality (7\%) and a uniform increase in functional class. The significance of these cumulative results is profound considering that the only alternative for many of these patients is cardiac transplantation, which was subsequently performed once in McElhinney's series ${ }^{13}$ and once in Kreutzer's series. ${ }^{14}$

The rationale for arrhythmia therapy in these previously reported cases ${ }^{12-15}$ was based on reduction atrioplasty and elimination of the high-pressure atrium $^{25-27}$ by lateral tunnel or extracardiac techniques. Except for perioperative atrial antitachycardia pacemaker placement in selected patients, no specific attempt at arrhythmia circuit interruption was made. As a consequence, atrial arrhythmias persisted in a significant number of their patients and developed anew in others who had extensive atrial reduction. ${ }^{13}$ These results are not surprising based on experimental animal studies by Gandhi and associates ${ }^{32}$ that implicated preexisting Fontan 
intraatrial suture lines as the substrate for reentry atrial tachycardia. In a concurrent comparative clinical report, ${ }^{16}$ we found that atriopulmonary Fontan conversion to total cavopulmonary artery connection without arrhythmia circuit cryoablation results in uniform recurrence of atrial arrhythmias, supporting in human beings what was found in Gandhi's animal studies. ${ }^{32}$ We conclude from these studies that preexisting Fontan atrial suture lines are critical to the pathogenesis of reentry atrial tachycardia and that relief of atrial hypertension by means of lateral tunnel or extracardiac techniques, although important for optimal hemodynamic results, will not effectively control atrial arrhythmias unless accompanied by arrhythmia circuit cryoablation.

Reoperation in Fontan patients with established atriopulmonary artery connection (with or without discontinuous pulmonary arteries) involves three important components to achieve improved hemodynamics and effective arrhythmia control. The first is safe resternotomy and effective total cavopulmonary artery reconstruction; the second is EP mapping and comprehensive arrhythmia circuit cryoablation; and the third, in our practice, is the prophylactic placement of an atrial antitachycardia pacemaker.

Resternotomy in Fontan patients with large, thinwalled, and oftentimes anterior right atria requires careful consideration of anatomic and pathophysiologic conditions that can easily be destabilized in the event of unwanted and uncontrolled cavitary entry. Indeed, one of our patients eventually died because of a presumed cerebral air embolism caused by cavitary entry during resternotomy despite expeditious femoral cannulation and effective total cavopulmonary artery conversion. In selected patients with the aforementioned risk factors (one in this series), we recommend femoral artery-femoral vein partial cardiopulmonary bypass to decompress the right atrium for more effective and safer resternotomy. ${ }^{13}$ After dissection, conversion to aortobicaval cannulation and femoral vessel repair is performed. Conversion from atriopulmonary to total cavopulmonary artery connection is relatively straightforward. In most cases, the pulmonary arteries must be completely dissected because a significant number of connections are anteroaortic and should be converted to a retroaortic position. All pulmonary artery stenoses should be addressed by arterioplasty (we prefer PTFE), which can be followed by intraatrial lateral tunnel or extracardiac inferior vena cava-pulmonary artery connection. The retrospec- tive reconstructive trends in this small series of patients are less use of atrial fenestration and greater use of aortic homografts and PTFE tubes for the extracardiac connection., 20, 21 Our unsubstantiated bias is to avoid atrial fenestration and systemic desaturation despite the increased cardiac output ${ }^{19}$ in favor of the resultant improved hemodynamics in a patient already adapted to the increased systemic venous pressure of the "Fontan physiology." The extracardiac connection is attractive because it is generally easier to perform and has the added benefit of fewer atrial suture lines that are one of the substrates for atrial tachycardia. ${ }^{33}$

The exact sites for arrhythmia circuit cryoablation in our patients were based on perioperative EP studies $^{16}$ and previous reports ${ }^{34-36}$ that defined the predominant anatomic critical isthmus for slow conduction in the area between the coronary sinus os, tricuspid anulus, and the inferior vena cava os. We identified three major anatomic sites thought to be critical to the tachycardia circuit (Fig. 2). These were Area 1, the area between the coronary sinus os and the inferior vena cava os, as well as the area between the atrioventricular valve anulus and the inferior vena cava os; Area 2, the lateral atriotomy, which corresponded to the length of the crista terminalis; and Area 3, the region at the superior limbus corresponding to the rim of the prior atrial septal defect patch. All patients had cryoablation lesions placed in Area 1. In those selected patients requiring further therapy in Areas 2 and 3, cryoablation lesions were linearly placed to connect these areas with an anatomic orifice (i.e., vertical lesions along the crista terminalis from the superior vena cava to the inferior vena cava or lesions to connect the superior limbus to the superior vena cava). With this strategy, all patients had acutely successful atrial arrhythmia ablation, although two patients had new atrial arrhythmias develop that were easily controlled with single-drug therapy.

Although we believe that the cryoablation technique is critical to interrupt the reentrant tachycardia circuit, the limitations of our mapping technique and the possibility of creating new arrhythmia substrates may result in postoperative tachycardia. Transvenous catheter access to the heart for radiofrequency catheter ablation or pacing will be limited postoperatively, particularly in patients with an extracardiac tunnel. Reoperation for placement of an antitachycardia pacemaker will require an additional sternotomy. The rationale for the atrial wire and antitachycardia pacemaker represents "backup 
therapy" in the event of cryoablation failure. Early in our experience, finding a favorable right atrial wire location for the antitachycardia pacemaker was often problematic because of the endocardial fibrosis often present in the right side of the atrium. We subsequently found that the left atrial appendage is a superior site, yielding favorable EP measurements. ${ }^{17}$ The advantages of this technique include accurate wire placement and fixation aided by cardioplegic arrest and lack of left atrial endocardial fibrosis because reconstructive suture lines are rarely placed in this area. The disadvantage of this technique is that the atrial wire can only be tested after cavitary closure and separation from cardiopulmonary bypass, when manipulation is severely limited. Thus far, we have not experienced systemic complications from the left-sided atrial wires, perhaps owing to the improved hemodynamics and long-term warfarin administration. ${ }^{37} \mathrm{We}$ therefore continue to recommend prophylactic atrial antitachycardia pacemaker placement in these patients to add another measure of therapy should cryoablation fail or a new arrhythmia circuit develop.

The primary indication for surgery in most of our patients was medically refractory atrial arrhythmias associated with syncope, stroke, or severe functional incapacity. Present-day management of atrial tachycardia in Fontan patients by pharmacotherapy, ${ }^{38}$ radiofrequency ablation, ${ }^{34-36}$ and antitachycardia pacing ${ }^{39}$ has met with variable success and significant morbidity. ${ }^{38}$ Our own comparative study ${ }^{16}$ and reports from others ${ }^{12-15,28}$ indicate that Fontan conversion without specific arrhythmia therapy improves hemodynamics but does not alter the course of atrial arrhythmias. We have shown that intraoperative mapping and selective cryoablation can interrupt the arrhythmia circuit in most patients without pharmacotherapy or dependence on atrial antitachycardia pacemakers.

Reoperation in Fontan patients with significant debilitating atrial arrhythmias with or without obstructive lesions can be accomplished with low morbidity and mortality, resulting in oftentimes dramatic increases in patient activity and function. We recommend that patients with atriopulmonary artery Fontan connections be closely followed up for obstructive lesions, valvular dysfunction, and atrial arrhythmias with a low threshold for reoperation, even if the only indication is debilitating atrial arrhythmias. Prophylactic cryoablation in first-time Fontan reconstructions to prevent atrial arrhythmias is an intriguing issue that will require a controlled study to determine its efficacy.

\section{REFERENCES}

1. Fontan F, Baudet E. Surgical repair of tricuspid atresia. Thorax 1971;26:240-8.

2. Kreutzer G, Galindez E, Bono H, DePalma C, Laura JP. An operation for the correction of tricuspid atresia. J Thorac Cardiovasc Surg 1973;66:613-21.

3. Puga FJ, Chiavarelli M, Hagler DJ. Modifications of the Fontan operation applicable to patients with left atrioventricular valve atresia or single atrioventricular valve. Circulation 1987;76(Suppl):III53-60.

4. de Leval MR, Kilner P, Gerwillig M, Bull C. Total cavopulmonary connection: a logical alternative to atriopulmonary connection for complex Fontan operations: experimental studies and early clinical experience. J Thorac Cardiovasc Surg 1988;96:682-95.

5. Bridges ND, Lock JE, Castaneda AR. Baffle fenestration with subsequent transcatheter closure: modification of the Fontan operation for patients at increased risk. Circulation 1990;82:1681-9.

6. Marcelletti C, Corno A, Giannico S, Marino B. Inferior vena cava-pulmonary artery extracardiac conduit: a new form of right heart bypass. J Thorac Cardiovasc Surg 1990;100:22832.

7. Fishberger SB, Wernovsky G, Gentles TL, et al. Factors that influence the development of atrial flutter after the Fontan operation. J Thorac Cardiovasc Surg 1997;113:80-6.

8. Mayer JE Jr, Bridges ND, Lock JE, Hanley FL, Jonas RA, Castaneda AR. Factors associated with marked reduction in mortality for Fontan operations in patients with single ventricle. J Thorac Cardiovasc Surg 1992;103:444-51.

9. Cetta F, Feldt RH, O'Leary PW, et al. Improved early morbidity and mortality after Fontan operation: the Mayo Clinic experience, 1987 to 1992. J Am Coll Cardiol 1996;28: 480-6.

10. Knott-Craig CJ, Danielson GK, Schaff HV, Puga FJ, Weaver AL, Driscoll DD. The modified Fontan operation: an analysis of risk factors for early postoperative death or takedown in 702 consecutive patients from one institution. J Thorac Cardiovasc Surg 1995;109:1237-43.

11. Feldt RH, Driscoll DJ, Offord KP, et al. Protein-losing enteropathy after the Fontan operation. J Thorac Cardiovasc Surg 1996;112:672-80.

12. Kao JM, Alejos JC, Grant PW, Williams RG, Shannon KM, Laks H. Conversion of atriopulmonary to cavopulmonary anastomosis in management of late arrhythmias and atrial thrombosis. Ann Thorac Surg 1994;58:1510-4.

13. McElhinney DB, Reddy VM, Moore P, Hanley FL. Revision of previous Fontan connections to extracardiac or intraatrial conduit cavopulmonary anastomosis. Ann Thorac Surg 1996; 62:1276-82.

14. Kreutzer J, Keane JF, Lock JE, et al. Conversion of modified Fontan procedure to lateral atrial tunnel cavopulmonary anastomosis. J Thorac Cardiovasc Surg 1996;111:1169-76.

15. Vitullo DA, DeLeon SY, Berry TE, et al. Clinical improvement after revision in Fontan patients. Ann Thorac Surg 1996;61:1797-804.

16. Deal BJ, Mavroudis C, Backer CL, DeLeon SY, Rocchini 
AJ. Surgical cryoablation of arrhythmia circuit in Fontan patients. Circulation 1996;94(Suppl):I176.

17. Johnsrude CL, Deal BJ, Backer CL, Mavroudis C, Herrel L, Strasburger JF. Short term follow-up of transmural atrial pacing leads in patients with postoperative congenital heart disease. PACE 1997;20(Pt II):1131.

18. Hoyer MH, Beerman LB, Ettedguis JA, Park SC, del Nido PJ, Siewers RD. Transatrial lead placement for endocardial pacing in children. Ann Thorac Surg 1994;58:97-101.

19. Mavroudis C, Zales VR, Backer CL, Muster AJ, Latson LA. Fenestrated Fontan with delayed catheter closure: effects of volume loading and baffle fenestration on cardiac index and oxygen delivery. Circulation 1992; 86(Suppl):II85-92.

20. Laschinger JC, Redmond JM, Cameron DE, Kan JS, Ringel RE. Intermediate results of the extracardiac Fontan procedure. Ann Thorac Surg 1996;62:1261-7.

21. van Son JA, Reddy VM, Hanley FL. Extracardiac modification of the Fontan operation without use of prosthetic material. J Thorac Cardiovasc Surg 1995;110:1766-8.

22. Pearl JM, Laks H, Stein DG, Drinkwater DC, George BL, Williams RG. Total cavopulmonary anastomosis versus conventional modified Fontan procedure. Ann Thorac Surg 1991;52:189-96.

23. Gardiner HM, Dhillon R, Bull C, de Leval MR, Deanfield JE. Prospective study of the incidence and determinants of arrhythmia after total cavopulmonary connection. Circulation 1996;94(Suppl):II17-21.

24. Girod DA, Fontan F, Deville C, Ottenkamp J, Choussat A. Long-term results after the Fontan operation for tricuspid atresia. Circulation 1987;75:605-10.

25. Driscoll DJ, Offord KP, Feldt RH, Schaff HV, Puga FJ, Danielson GK. Five to fifteen year follow-up after Fontan operation. Circulation 1992;85:469-96.

26. Peters NS, Sommerville J. Arrhythmias after the Fontan procedure. Br Heart J 1992;68:199-204.

27. Gelatt M, Hamilton RM, McCrindle BW, et al. Risk factors for atrial tachyarrhythmias after the Fontan operation. J Am Coll Cardiol 1994;24:1735-41.

28. Maragnes P, Villain E, Iselin M, David N, Foucault JP. Troubles du rythme auriculaire tardifs compliquant les oper- ations de type Fontan ou de type cavopulmonaire: a propos de 7 observations. Arch Mal Coeur 1996;89:605-9.

29. Cecchin F, Johnsrude CL, Perry JC, Friedman RA. Effect of age and surgical technique on symptomatic arrhythmias after the Fontan procedure. Am J Cardiol 1995;76:386-91.

30. Kopf GS, Laks H, Stansel HC, Hellenbrand WE, Kleinman CS, Talner NS. Thirty-year follow-up of superior vena cavapulmonary artery (Glenn) shunts. J Thorac Cardiovasc Surg 1990;100:662-70.

31. Cromme-Dijkhuis AH, Hess J, Hahlen K, et al. Specific sequelae after Fontan operation at mid- and long-term follow-up: arrhythmia, liver dysfunction, and coagulation disorders. J Thorac Cardiovasc Surg 1993;106:1126-32.

32. Gandhi SK, Bromberg BI, Schuessler RB, et al. Characterization and surgical ablation of atrial flutter after the classic Fontan repair. Ann Thorac Surg 1996;61:1666-78.

33. Gandhi SK, Bromberg BI, Rodefeld MD, et al. Lateral tunnel suture line variation reduces atrial flutter after the modified Fontan operation. Ann Thorac Surg 1996;61:1299-309.

34. Triedman JK, Saul JP, Weindling SN, Walsh EP. Radiofrequency ablation of intra-atrial reentrant tachycardia after surgical palliation of congenital heart disease. Circulation 1995;91:707-14.

35. Kalman JM, VanHare GF, Olgin JE, Saxon LA, Stark SI, Lesh MD. Ablation of "incisional” reentrant atrial tachycardia complicating surgery for congenital heart disease: use of entrainment to define a critical isthmus of conduction. Circulation 1996;93:502-12.

36. Lesh MD, Van Hare GF, Epstein LM, et al. Radiofrequency catheter ablation of atrial arrhythmias: results and mechanisms. Circulation 1994;89:1074-89.

37. Jahangiri M, Ross DB, Redington AN, Lincoln C, Shinebourne EA. Thromboembolism after the Fontan procedure and its modifications. Ann Thorac Surg 1994;58:1409-13.

38. Balaji S, Johnson TB, Sade RM, Case CL, Gillette PC. Management of atrial flutter after the Fontan operation. J Am Coll Cardiol 1994;23:1209-15.

39. Case CL, Gillette PC, Zeigler V, Sade RM. Problems with permanent atrial pacing in the Fontan patient. PACE 1989;12: 92-6. 